\title{
Antecedents and Consequences of Individual Performance: Analysis of Turnover Intention Model (Empirical Study of Public Accountants in Indonesia)
}

\author{
${ }^{1}$ Hendra Raza*, ${ }^{2}$ Azhar Maksum, ${ }^{2}$ Erlina, ${ }^{2}$ Prihatin Lumban Raja \\ ${ }^{1}$ Universitas Malikussaleh, Lhokseumawe, Indonesia \\ 2Universitas Sumatera Utara, Medan, Indonesia \\ *hendra.razaunimal@yahoo.com
}

\begin{abstract}
This study aims to examine empirically the antecedents of individual performance on its consequences of turnover intention in public accounting firms. There are eight variables measured which consists of auditors' empowerment, innovation, professionalism, role ambiguity, role conflict, organizational commitment, individual performance and turnover intention. Data analysis is based on 163 public accountant using the Structural Equation Modeling assisted with an application of the Analysis Moment Structure (AMOS). The findings have revealed that the model is acceptable and successfully proves on a significant influence of the auditors' innovation on the role ambiguity, professionalism on the role ambiguity, empowerment on the role conflict, innovation on the role conflict, professionalism on the role conflict, role conflict on the organizational commitment, role ambiguity on the auditors' performance, organizational commitment on the auditors' performance, auditors' empowerment on the turnover intention, innovation on the turnover intention, professionalism on the turnover intention, organizational committment on the turnover intention, auditors' performance on turnover intention. The new variables of auditors' empowerment and innovation in the model as well as the direct influence of performance on turnover intention are successfully proven.
\end{abstract}

Keywords: Auditors' empowerment, innovation, professionalism, role ambiguity, role conflict, organizational commitment, individual performance and turnover intention

\section{Introduction}

There is a phenomenon that public accountants have the desire to move up a level higher than other professionals, where they plan to move from a public accounting firm to another public accounting firm. Ratnawati (2001) finds that 85 percent of professional accountants who had joined the firm had left their job to look for other alternative jobs. It is aligned with a study by Collins (1993) whereby the public accountants especially women, have a high desire to move to other firms (or more than $50 \%$ of them). Bao et al. (1986) report a turnover rate for employees who are working at the public accountant firms that reaches 45 percent, while Lampe and Earnest (1984) reveal the junior auditors' turnover rate of about 23.9 percent annually. Toly (2001) suggests that an organizational performance is determined by the condition and behavior of the employees. It is common occurrence that the well-performing organizations can be tampered with, either directly or indirectly, by a variety of employee behaviors that are difficult to prevent. One of the forms is the employees' behavior in developing the intention to leave the job. The contribution of these studies on the literature is by providing evidence that the performance variable serves as a determinant variable to turnover intention. The performance variable is rarely tested as the antecedent variable in the turnover intention model. This model development is different from previous studies as it includes the examination of variables that is importantly useful in the public accountant firms, namely, auditors' empowerment and innovation. An auditor who has empowerment, innovation and is highly professional will contribute to the good name and image of the public accountant firms. This study has also successfully developed the instruments on innovation by Margison and Binh (2009), that is from three to six questions whereby the development of the questions in those instruments has become a special instrument for an innovative auditor.

The antecedents of individual performance consist of empowerment, innovation, professional; while, the role ambiguity and conflict used as the variables perceived by the public accountants would affect the performance widely. Meanwhile, the organizational commitment refers to a desire to maintain membership in an organization or profession which has been adopted as an important variable (Aranya et al., 1981). The study also examines the consequences of performance on turnover intention in public accountant firms. This model of performance and turnover intention analysis is chosen because the 
findings in existing studies do not show the consistency and very seldom find any researches that directly test the performance on the turnover intention of auditors. This research provides empirical evidence of the public accountants and public accountant firms on the influence and direction of the relationship among the variables of empowerment, innovation, professional, role ambiguity, role conflict, organizational commitment, performance and turnover intention, so that the rate of auditors' turnover can be reduced. This study refers to both behavioral and role theories. The theory emphasizes on the role of individual characteristics as social actors who learn behaviors according to the position they occupy in the workplace and society. Individuals will experience conflicts in themselves when there are two or more pressure occurring simultaneously addressed in a person (Burney \& Widener, 2007). Murtiasri (2006) states that the auditor is a profession closely related to conditions of stress because of the work pressure and the fact that the role of accounting profession is considered as one of the ten professions with the highest stress level in the United States (Bamber \& Tubbs, 1989).

\section{Literature Review}

The Influence of Auditors' Empowerment, Innovation and Professionalism on Role of Ambiguity: Drake et al. (2007) define empowerment as the intrinsic motivation that appears in the four cognitions reflecting an individual's orientation toward work roles in the sense of meaning, competence, selfdetermination and impact. Wetzel et al. (2000) have found that empowerment negatively affects the role ambiguity due to the relatively low level of expertise so that difficulties can be overcome in understanding superiors' orders. The role ambiguity relates to performance consequences which cannot be predicted, that has deficiency of information on the expected role of behavior. Drake et al. (2007) state that employees who have the motivation at work has a key role in the organizations' success which has been indicated by previous studies on a positive relationship between empowerment and motivation. In his prominent model, Spreitzer (1996) argues that the control system affects the feeling of empowerment, performance feedback and reward systems, thus the workers who feel empowered will have high motivation to improve their performance. Robbins (2003) suggests that empowerment makes employees master what they do. Empowerment means encouraging and allowing personal responsibilities in improving the operations, and increasing the contribution to the organization. Empowerment is the act of giving authority, skills and freedom to employees in performing their duties. Spreitzer (1996) describes it as the way people see themselves in the work environment in establishing the works' role. The increased empowerment can reduce the stress experienced in the workplace because it allows the utilization of the skills, knowledge and abilities as well as enables the employees to actively participate in it.

The public accountant firms need the innovative auditors. The auditors who have high innovation will enhance their progress and enhance the role ambiguity in the firms. In facing the advancement on public accountants' operations, Cahyono (2008) argues that auditors need to continually learn new roles through innovative actions whereby the higher innovation will lead to higher auditors' role ambiguity. Menwhile, according to Fridati (2005), a professional auditor has a duty to meet the specific rules of behavior, which describe an attitude or ideal things. That obligation can serve to be a fundamental responsibility for the profession to strengthen the services offered. Someone is seen to have a greater professional responsibility because it is assumed that a professional has the intelligence, knowledge and experience to understand the impact of the activities conducted. Khikmah (2005) suggests that professionalism affects the turnover intention mediated by organizational commitment and job satisfaction. Therefore, an auditor who has empowerment, innovation and is highly professional intends to play a larger role, so that the role becomes unclear, thus the higher auditor's professional results in higher role ambiguity.

H1a : Auditors' empowerment has an influence on the role ambiguity.

H1b: Auditors' innovation has an influence on the role ambiguity.

H1c: Auditors' professionalism has an influence on the role ambiguity.

The Influence of Auditors' Empowerment, Innovation and Professionalism and the Role Conflict: The empowerment will increase the desire to enhance the role of public accountants to a higher level on role conflict. Wetzel et al. (2000) find that empowerment negatively affects the role conflict. Meanwhile, Cahyono, (2008) has mentioned that the researches on mentoring in public accounting firms or the new entrant firms will experience the ambiguity and role conflict. The errors in mentoring will increase the role conflict and ambiguity through an indicator that a newcomer will have the difficulty in adapting to the situation. Mentoring is a form of empowerment for the public accountants' staff and as a process of 
developing and maintaining relationships that take place intensively between senior employees and junior employees. According to Cahyono (2008) in a public accountant firm, employees are likely to experience higher levels of stress. Generally, employees are assigned to several public accountant work agreements during the fiscal year, work with regulatory officers that conflicts with a variety of management styles and the work environment has unpredicted variables, even contradicted the matters with clients, agencies, professional standards, rules and procedures of the organization. The auditors are continually learning new roles, but when auditors are empowered, it may increase the role conflict.

The theory of multiple forms on role conflict has a multidimensional view that is never been investigated, that refers to a conflict between the employee's own role and his job, employer and employees, employees and the clients in public accountant firms. While, innovation refer to an implementation of new ideas in accordance with objectives of the organization. An auditor that is highly innovative, he or she will enhance and increase the role conflict (Schroeder \& Scudder, 1989). Fridati (2005) suggests that the auditors who are highly professional will give a good contribution to the public accountant firms and provide optimum service to its clients. The general auditing standards emphasize on the importance of possession towards personal qualities, namely, (i) gaining sufficient skills and training techniques, having a formal education in the fields of accounting and auditing, obtaining appropriate audit training that follows the professional education continously, (ii) having an independent mental attitude, (iii) running the audit in professional ways thoroughly and extensively. An auditor with empowerment, innovation and is highly professional enhances his or her role further, thus, higher role conflict tends to occur.

H2a: Auditors' empowerment has an influence on role conflict.

$H 2 b$ : Auditors' innovation has an influence on role conflict.

H2c: Auditors' professionalism has an influence on role conflict.

The Influence of Auditors' Empowerment, Innovation, Professionalism, Role Ambiguity and Conflict on the Organizational Commitment: Organizational commitment is a concept that seeks for the nature of attachment formed by individuals towards their work in the organization (Ketchan \& Strawser, 2001). Kreitner and Kinichki (2001) state that organizational commitment shows the individuals' identification and execution of organizational objectives. Research on organizational commitment initiated to identify the factors which influence the formation of organizational commitment and how it affects the organization. Meanwhile, innovation begins with creative ideas and can bring a tremendous success for the company. In certain occasions, innovation has the capacity to improve performance, solve problems, add value and create competitive advantage. Moreover, innovation can generally be described as an implementation of the discovery and modification as well as the processes that produce outcomes of a new, product, system or process.

The role theory suggests that based on certain conditions, the improvement in performance will decrease (Miles \& Perreault, 1976; King \& King, 1990). Performance and intellectual models play a major role as a source of innovation, therefore, the business strategy needs to give primary attention on these three aspects (performance, intellectual capital, innovation). The role conflict of each person plays a number of different roles and sometimes those roles bring contrary expectations. It often occurs to the persons who are holding several different roles with the same conflicting patterns of behavior. There are at least two kinds of role conflict, namely; (i) the conflict between various roles and conflict in a single role. In the meantime, the factors that influence the role ambiguity and conflict are the bureaucracy in organization and employee positions in the organizational hierarchy. According to Amilin and Dewi (2008), organizational commitment can grow when the expectations of organizations are managed appropriately, thus it can be concluded that the auditors' empowerment, innovation, professionalism, role ambiguity and conflict are positively related to organizational commitment.

H3a: Auditors' empowerment has an influence on organizational commitment.

H3b: Auditors' innovation has an influence on organizational commitment.

H3c: $\quad$ Auditors' professionalism has an influence on organizational commitment.

H3d: $\quad$ The role ambiguity has an influence on organizational commitment.

H3e: $\quad$ The role conflict has an influence on organizational commitment

The Influence of Role Ambiguity, Conflict and Organizational Committment on Performance: The organization depends on the creativity and innovation in order to survive in the global economy (Bartlett, C.A. \& Ghoshal, 1993; Marginson, 2002). Innovation relates to the knowledge that can be used to create products or processes, new services to increase competitive advantage and meet the ever-changing customer needs. Meanwhile, Amilin and Dewi (2008) refer to role ambiguity as a lack of understanding on 
rights, privileges and obligations of a person to do the job. The more often an individual is engaged and loyal in an organization, the higher commitment can be achieved for the organization, while lower in commitment has ambiguity in the roles. Andraeni (2003) states that role ambiguity is negatively related to physical health. Both role ambiguity and conflict can hinder a person from carrying out their duties, thus reducing organizational commitment. A lower organizational commitment results in a decrease in performance.

H4a: $\quad$ Role ambiguity has an influence on performance.

H4b: $\quad$ Role conflict has an influence on performance.

H4c: $\quad$ Organizational committment has an influence on performance

The Influence of Auditors' Empowerment, Innovation, Professionalism, Organizational Committment and Performance on Turnover Intention: According to Yousef (2000) staff who tend to be more committed to the organization are more likely to embrace change than those who are less committed to the organization. The public accountants who are more committed will improve their performance. The organizational commitment used as a mediator affects job security, job satisfaction, motivation and performance. The higher rate of performance relates to higher organizational commitment. Amilin and Dewi (2008) states that the success from a person's performance in any of the work subject is determined by the level of competence, professionalism and commitment towards the field of interest. An individual's performance will be affected by the level of job satisfaction, while, job satisfaction is influenced by someone either from within or from outside the organizations. Amilin and Goddess also states that high organizational commitment implies higher role conflict. A strong relationship occurs between professional commitment and job satisfaction in the presence of role conflict. It can be interpreted that the professional commitment contributes greater to job satisfaction when role conflict occurs.

The organizational commitment is the relative strength of an individual's identification and involvement in the organization (Meyer et al., 1989). The high organizational commitment of an individual carries with it higher acceptance of the goals and values of the organization, he then will strive earnestly to the interests of the organization and will wish to maintain membership in the organization, so that the turnover intention is low. Several studies show a positive relationship between the congruence of corporate, employee values and organizational commitment (Posner, 1993) and an inverse relationship between the congruence of corporate and labor turnover (O'Reilly et al., 1991). The concept model of turnover is largely expressed in the psychology literature as proposed by Mobley (1977, in Lum et al., 1998). The model considers the organizational commitment as an attitude that is associated with satisfaction and has the causal relationship between the two variables. Meanwhile, William and Hazer (1986) adopt a structural equation methodology, and they have posited that commitment has more crucial influence on the intention to stay rather than satisfaction.

The personal and organizational characteristics are found to have a direct influence on the turnover intention. Several studies have found that there is a negative relationship between organizational commitment, job satisfaction and turnover intention (Aranya \& Feris, 1984; Kalbers \& Forgathy, 1995). Bateman \& Stresser (1984) have suggested that many early studies have limitations because the interpretation tends to use the static correlation analysis of the relationship between commitment and its antecedents, while another study states that there is no linear relationship between commitment and turnover. The high turnover of public accountants might be due to low levels of organizational commitment that lead to the low performance. Thus, the organizational commitment of public accountants has an influence on the performance and turnover intention.

H5a: Auditors' empowerment has an influence on the turnover intention.

H5b: Auditors' innovation has an influence on the turnover intention.

H5c: $\quad$ Auditors' professionalism has an influence on the turnover intention.

H5d: Organizational committment has an influence on the turnover intention.

H5e: $\quad$ Auditors' performance has an influence on the turnover intention.

\section{Methodology}

Sampling Frame and Data Collection: The research data were collected by sending questionnaires through the postal mail. The list of public accounting firms obtained from the Directory of Public Accountant and Certified Public Accountants was issued by the Indonesian Institute of Certified Public Accountants (IAPI) in 2011. The members of the IAPI who are registered with the Ministry of Finance as 
of January 28, 2011 are 1,322 accountants consisting of 920 CPAs and 402 of non-CPAs. The questionnaires were sent to 902 accountants or to 451 public accounting firms.

Validity and Reliability Tests: Validity test results have shown that all of the items are valid, while the reliability coefficient of the questionnaire examining the five variables are all greater than 0.7 , so that it can be concluded that the instrument measures used in this study have given consistent results.

\section{Variables Operationalization}

- The empowerment variable was measured using an instrument that was adopted from Margison and Binh (2009), which consists of 5 questions with a 5-point interval scale ranging from strongly disagree (1) to strongly agree (5).

- An individual innovation measured by using an instrument was developed by Margison and Binh (2009) having 3 questions with a scale of 5 points interval scale ranging from strongly disagree (1) to strongly agree (5). This questionnaire developed the instrument and it was translated into the formation of 6 questions.

- Indicators for auditor professionalism were adopted from Wahyudi and Mardiyah (2006) consist of 24 questions using 5 dimensions of professional auditors.

- The role of ambiguity variable was measured with 6 indicators.

- Role conflict instrument consists of 12 questions with a scale of 5-point interval scale ranging from strongly disagree (1) to strongly agree (5).

- The organizational commitment was measured using the Organizational Commitment questionnaire (OCQ) adopted from Darlis (2000) consisting of 9 questions with 5 point Likert scale ranging from strongly disagree (1) to strongly agree (5)

- Performance was measured using an instrument that was adopted from Fisher (2001) consisting of 12 questions with a 5-point interval scale ranging from strongly disagree (1) to strongly agree (5).

- Turnover intention. The research instrument of this variable was adopted from Pujisari (2001) which consists of 5 questions answered with a 5-point interval scale ranging from strongly disagree (1) to strongly agree (5).

\section{Findings and Discussion}

Respondent Profile: The data were obtained from a total of 902 questionnaires that had been distributed to all public accountant offices in Indonesia. Each office received two questionnaires with only 163 questionnaires returned or with $18.03 \%$ return rate. This shows that the level of response rate is suffice for the size of Indonesia by average of 10-20 percent. All of these questionnaires were used for data analysis consisting of $97(59.50 \%)$ male respondents and 66 (40.50\%) female respondents.

Normality Test: Table 1 and 2 present the summary of the multivariate normality test on the first model. As noted by Bryman and Cramer (2001), the value of the critical ratio> 5.00 indicates that the data are not multivariate normal distribution, thus the data with the largest outliers need to be removed. After the data were removed, the value of the critical ratio dropped to 4.978, so that it can be assumed that the data were normally distributed and could be continued in the subsequent analysis.

Table 1: Summary of multivariate normality test on the first model

\begin{tabular}{lllllll}
\hline Variable & min & $\max$ & Skew & c.r. & kurtosis & c.r. \\
\hline Multivariate & & & & & 176.514 & 10.216 \\
\hline
\end{tabular}

Table 2: Summary of multivariate normality test on the last model

\begin{tabular}{lllllll}
\hline Variable & min & max & Skew & c.r. & kurtosis & c.r. \\
\hline Multivariate & & & & & 92.159 & 4.978 \\
\hline
\end{tabular}

Multicollinierity Assumption: The assumption of multicollinearity was tested to determine whether or not there is a strong correlation between variables or even perfectly related among the variables' measurements and latent variables. In this study, the multicollinearity test is done by observing the output of the correlation matrix using the AMOS program on the correlation of pairwise comparison parameter estimates. Based on the observation of a correlation matrix, it is revealed that a correlation coefficient is greater than 0.80 , therefore the conclusion that can be made is that there are no multicollinearity problems among measurements and latent variables. 
Significance of the Model (Goodness of Fit): The test of goodness of fit aims to determine whether the model has been obtained appropriately in describing the relationship among variables. A test model fit in the structural equation modeling can be analyzed based on several criteria such as testing the suitability of the model as presented in the following table.

Table 3: Summary of Goodness of Fit Model Test

\begin{tabular}{llll}
\hline Index & Estimation Value & GOF Test Criteria & Test Result \\
\hline CMIN & $4997(\mathrm{DF}=2830)$ & & \\
p-value & $<0.001$ & $\mathrm{p}>0.05$ (fit) & \\
CMIN/DF & 1.766 & $<2$ (marginal fit) & The Model is \\
RMSEA & 0.074 & $<0.08$ (fit) & Accepted \\
RMR & 0.042 & $<0.05$ (fit) \\
GFI & 0.554 & $>0.90$ (marginal fit) & \\
AGFI & 0527 & $>0.90$ (marginal fit) & \\
\hline
\end{tabular}

Based on the results in Table 3. It can be seen from the overall model fit test that the model estimation results are acceptable, meaning that the empirical model is related to other theoretical models.

\section{Figure 1: Standard Coefficient of Full Model}

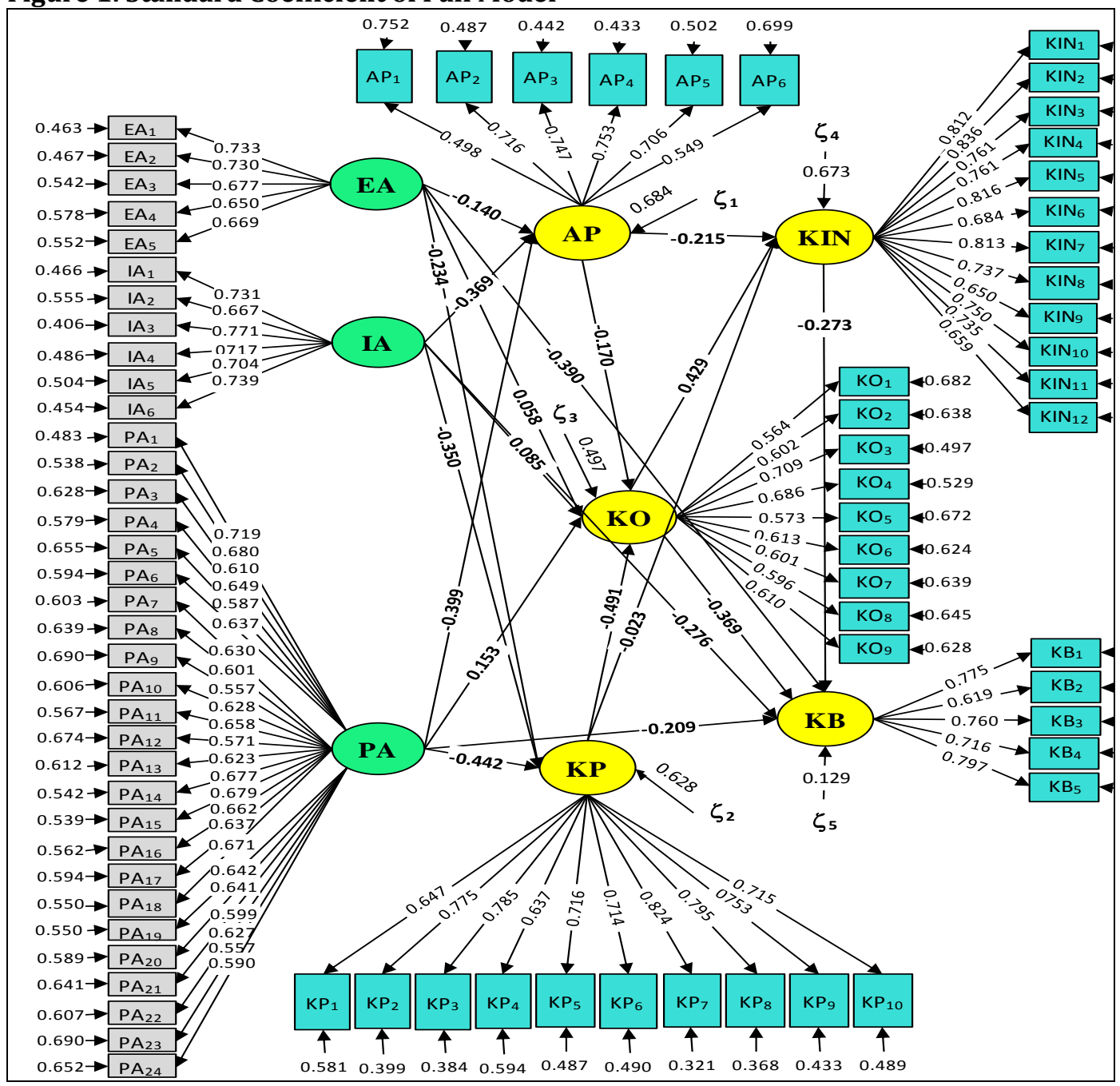

Measurement Model: The measurement model links between latent variables to the manifest variables. There are 8 latent variables with a total of 77 manifest variables. The results for model goodness of fit is acceptable, thus it can be used to test the proposed research hypotheses. It is followed with the validity test of each indicator of the latent variables. The indicators are valid if it they have a weight factor greater than 0.45 and the critical ratio is greater than 1.96. Figure 1. below presents the full path diagram model. 
Measurement Model Latent Variables of Auditors' Empowerment: The measurement on latent variables of empowerment, innovation, professional, role ambiguity, role conflict, organizational commitment and performance as well as the auditor's turnover intention adopt the weight values in each indicator greater than the value of critical ratio of 0.45 , while all the critical value ratios was $>1.96$, meaning that all are valid indicators used as a tool to measure the latent variables.

Structural Model: The structural analysis models aims to identify the causal relationships among latent variables. This model is a model that links the latent exogenous variable and latent endogenous variable or the latent endogenous variables with other latent endogenous variables. Based on the existing research paradigm, there are five structural models that will be tested in this study, which are mathematically formulated as follows :

Role Ambiguity (AP) $=\gamma_{1.1} \mathrm{EA}+\gamma_{1.2} \mathrm{IA}+\gamma_{1.3} \mathrm{PA}+\zeta_{1}$

Role Conflict (KP) $=\gamma_{2.1} \mathrm{EA}+\gamma_{2.2} \mathrm{IA}+\gamma_{2.3} \mathrm{PA}+\zeta_{2}$

Organizational Committment $(\mathrm{KO})=\gamma_{3.1} \mathrm{EA}+\gamma_{3.2} \mathrm{IA}+\gamma_{3.3} \mathrm{PA}+\beta_{2.1} \mathrm{AP}+\beta_{2.2} \mathrm{KP}+\zeta_{3}$

Auditors' Performance (KIN) $=\beta_{3.1} \mathrm{AP}+\beta_{3.2} \mathrm{KP}+\beta_{3.3} \mathrm{KO}+\zeta_{4}$

Turnover Intention $(\mathrm{KB})=\gamma_{4.1} \mathrm{EA}+\gamma_{4.2} \mathrm{IA}+\gamma_{4.3} \mathrm{PA}+\beta_{4.1} \mathrm{KO}+\beta_{4.2} \mathrm{KIN}+\zeta_{5}$

Based on the results of the processed data using AMOS software, the estimation results obtained from the five structural models are presented in the form of a path diagram as follows:

Figure 2: Path Diagram of the Research

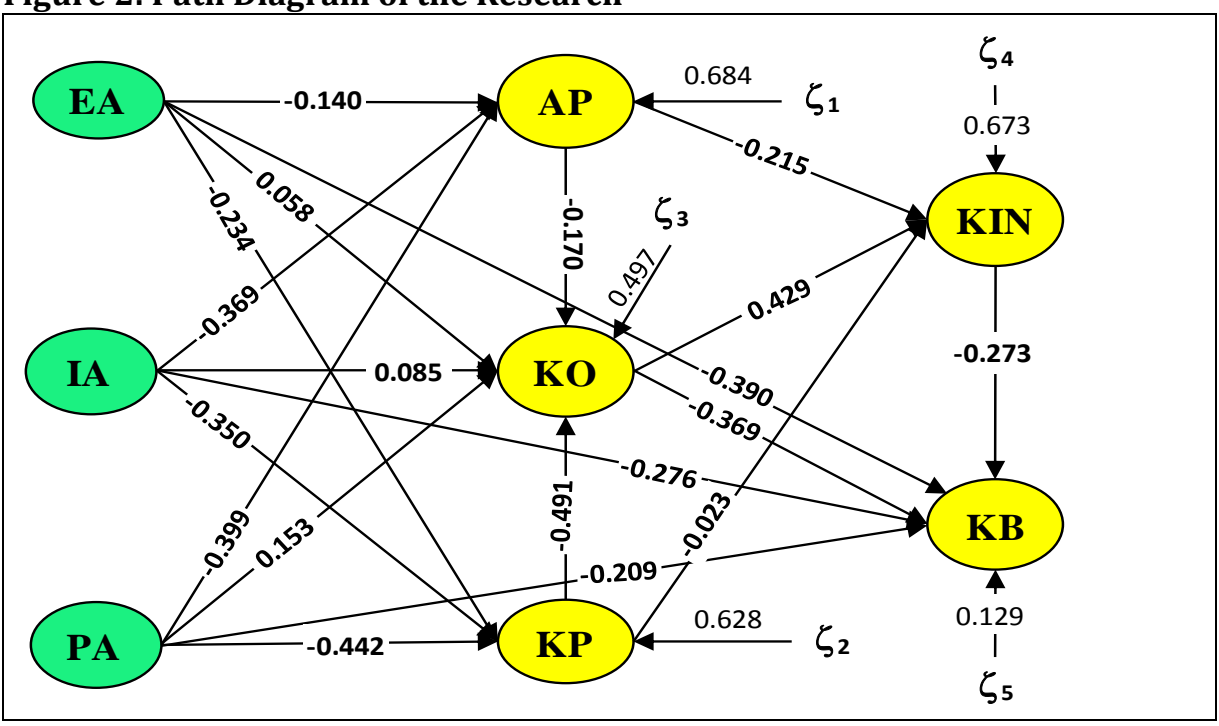

Meanwhile, the estimation of the structual equation on the five models can be summarized as presented in the following table:

The Effect of Auditors' Empowerment, Innovation and Professionalism Against The Role Ambiguity: As shown in Table 4, it can be seen that the value of R-square of the first sub-structure is 0.316, which means the auditors' empowerment, innovation and professionalism simultaneously affect $31.6 \%$ the role ambiguity. Meanwhile, the remaining $68.4 \%$ is influenced by other factors. The hypothesis tests to prove whether there is an influence of auditor's empowerment, innovation and professionalism against the role ambiguity. Based on the results depicted in Table 4., it can be seen that the path coefficient of auditors' empowerment, innovation and professionalism variables on the role ambiguity is $0.140,0.369$ and 0.399 respectively with all have a negative direction, meaning that the higher the auditor's empowerment, innovation and professionalism the lower the role ambiguity. The statistically critical ratio value for the empowerment variable is 1.543 or less than 1.96 , which indicates that the test results are not significant, while both variables of innovation and professionalism have a value of 3.448 and 3.696 respectively which are more than 1.96 or it indicates that the results are significant. Each of these two variables have direct influence to the role ambiguity on public accountants by $(0.369)^{2}=13.6 \%$ and $(0.399)^{2}=15.9 \%$. Thus, both $\mathrm{H} 1 \mathrm{~b}$ and $\mathrm{H} 1 \mathrm{c}$ are supported but unfortunately, H1a is unsupported. 
Table 4: Summary of Hypotheses Test

\begin{tabular}{lllll}
\hline Sub-Structure & Path & Coefficient Path & C.R* & R-Square \\
\hline First & EA $\rightarrow$ AP & -0.140 & -1.543 & 0.316 \\
& IA $\rightarrow$ AP & -0.369 & -3.448 & \\
Second & PA $\rightarrow$ AP & -0.399 & -3.696 & \\
& EA $\rightarrow$ KP & -0.234 & -2.747 & 0.372 \\
Third & IA $\rightarrow$ KP & -0.350 & -3.903 & \\
& PA $\rightarrow$ KP & -0.442 & -4.694 & \\
& EA $\rightarrow$ KO & 0.058 & 0.699 & 0.503 \\
& IA $\rightarrow$ KO & 0.085 & 0.900 & \\
Fourth & PA $\rightarrow$ KO & 0.153 & 1.572 & \\
& AP $\rightarrow$ KO & -0.170 & -1.655 & \\
Fifth & KP $\rightarrow$ KO & -0.491 & -3.936 & \\
& AP $\rightarrow$ KIN & -0.215 & -2.164 & 0.327 \\
& KP $\rightarrow$ KIN & -0.023 & -0.204 & \\
& KO $\rightarrow$ KIN & 0.429 & 3.127 & \\
& EA $\rightarrow$ KB & -0.390 & -5.515 & 0.871 \\
& IA $\rightarrow$ KB & -0.276 & -4.194 & \\
& PA $\rightarrow$ KB & -0.209 & -3.223 & \\
& KO $\rightarrow$ KB & -0.369 & -3.863 & \\
& KIN $\rightarrow$ KB & -0.273 & -4.000 & \\
\hline
\end{tabular}

${ }^{*}$ Critical Value $=1,96$

The Effect of Auditors' Empowerment, Innovation and Professionalism Against The Role Conflict: As presented in Table 4., the second sub-structure has the value of R-square of 0.372 , indicating that the auditors' empowerment, innovation and professionalism simultaneously affect $37.2 \%$ of the role conflict. Meanwhile the rest of $62.8 \%$ are affected by other factors. Table 4 . reveals that the path coefficient of auditors' empowerment, innovation and professionalism variables on the role conflict is $0.234,0.350$ and 0.442 respectively with all having a negative direction, indicating that the higher auditor's empowerment, innovation and professionalism would make lower role conflict. All the statistical critical ratio values for the three variables of $2.747,3.903$ and 4.694 which are more than 1.96 point to the significant results. Each of these has a direct influence to the role conflict on public accountants by $(0.234)^{2}=5.5 \%,(0.350)^{2}$ $=12.3 \%$ and $(0.442)^{2}=19.5 \%$ respectively. Thus, $\mathrm{H} 2 \mathrm{a}, \mathrm{H} 2 \mathrm{~b}, \mathrm{H} 2 \mathrm{c}$ are supported.

The Effect of Auditors' Empowerment, Innovation, Professionalism, Role Ambiguity and Conflict on Organizational commitment: The third sub-structure as depicted in Table 4 has the value of Rsquare of 0.503 , and this implies that the auditors' empowerment, innovation and professionalism, role ambiguity and conflict have simultant effect of $50.3 \%$ on the organizational committment, while the remaining of $49.7 \%$ is influenced by other factors. It is found that the path coefficient of auditors' empowerment, innovation and professionalism variables on organizational committment is $0.058,0.085$ and 0.153 respectively with all having a positive direction, further suggesting that the higher the auditor's empowerment, innovation and professionalism the higher the organizational committment; whereas for the role ambiguity and conflict, each has the path coefficient of 0.170 and 0.491 with a negative direction, indicating that the higher role ambiguity and conflict would lead to the lower organizational committment. All the statistical critical ratios for the four variables subsequently have a value of 0.699 , $0.900,1.574$ and 1.655 which are less than 1.96 or indicating the insignificant results, while a variable of role conflict obtains 3.939 which is more than 1.96 or meaning that the results are significant which influences directly the organizational committment on public accountants by $(0.491)^{2}=24.1 \%$. Thus, $\mathrm{H} 3 \mathrm{e}$ is supported and $\mathrm{H} 3 \mathrm{a}, \mathrm{H} 3 \mathrm{~b}, \mathrm{H} 3 \mathrm{c}, \mathrm{H} 3 \mathrm{~d}$ are not supported.

The Effect of Role Ambiguity, Conflict, and Organizational committment on Auditors' Performance: The fourth sub-structure as depicted in Table 4 . has the value of R-square of 0.327 , indicating that the role ambiguity and conflict, and organizational committment simultanenously are affected by $50.3 \%$ on auditors' performance, while the remaining of $32.7 \%$ is influenced by other factors. As presented in Table 4., it is found that the path coefficient of the role ambiguity and conflict, and organizational committment variables on the auditors' performance is 0.390 and 0.023 respectively with a negative direction, indicating that the higher role ambiguity and conflict would make lower auditors' performance; while the organizational committment has the path coefficient of 0.429 with a positive direction, indicating that the higher organizational committment would make higher auditors' performance. Each of the critical ratio 
values for the role ambiguity and organizational committment are 2.127 and 3.127 which is more than 1.96 or indicating some significant results, but for the role conflict it is 0.204 , or indicating an insignificant result. The two variables have a direct influence on auditors' performance on public accountants by $(0.215)^{2}=4.6 \%$ and $(0.429)^{2}=24.1 \%$ respectively. Thus, $\mathrm{H} 4 \mathrm{a}$ and $\mathrm{H} 4 \mathrm{c}$ are supported, while $\mathrm{H} 4 \mathrm{~b}$ is unsupported.

The Effect of Auditors' Empowerment, Innovation and Professionalism, Organizational committment and Auditors' Performance on Turnover Intention: The fifth sub-structure is shown in Table 4. It has the value of R-square of 0.871 , which indicates that auditors' empowerment, innovation, professionalism, organizational committment and performance are simultaneously affected by $87.1 \%$ on turnover intention, while the remaining of $12.9 \%$ are influenced by other factors. As depicted in Table 4 ., it is found that the path coefficients of auditors' empowerment, innovation and professionalism, organizational committment and auditors' performance variables on turnover intention of $0.390,0.276$, $0.209,0.369$ and 0.273 respectively have a negative direction, indicating that the higher auditors' empowerment, innovation, professionalism, organizational committment and performance would lead to lower rates of turnover intention. Each of the critical ratio values for the auditors' empowerment, innovation, professionalism, organizational committment and performance are 5.515, 4.194, 3.223, 3.863 and 4.000 which is more than 1.96 or they indicate significant results on turnover intention. The five variables have direct influence on the turnover intention on public accountants in Indonesia by $(0.390)^{2}=$ $15.2 \%,(0.276)^{2}=7.6 \%,(0.209)^{2}=4.4 \%,(0.369)^{2}=13.6 \%$ and $(0.273)^{2}=7.5 \%$ respectively. Thus H5a, $\mathrm{H} 5 \mathrm{~b}, \mathrm{H} 5 \mathrm{c}, \mathrm{H} 5 \mathrm{~d}$, and $\mathrm{H} 5 \mathrm{e}$ all are supported.

\section{Conclusion}

This study on individual performance of public accountants in Indonesia needs to be conducted to prove that each of the dimensions has a relationship with the dependant variables as found by authors mentioned in the literature review. For the variable of auditors' empowerment, there are arguments that go particularly againts the findings by Wetzel et al. (2000) on the role ambiguity and conflict, followed by Alam and Armanu (2010), Spreitzer (1996) and Robbins (2003) on organizational committment and turnover. Meanwhile, the result on the relationship of auditor's innovation variable on the role of ambiguity, conflict, organizational committment as well as turnover has revealed a consistency with findings by Margison and Binh (2009) and Schroeder and Scudder (1989). Moreover, the findings on the effect of auditors' profesionalism towards the role ambiguity, conflict and turnover is aligned with the statement by Fridati (2005) and Khikmah (2005) but eventually this independent variable has an insignificant relationship with the organizational committment which has been agreed by Khikmah (2005). For the role of ambiguity as a variable, it is found to have significant relationship with auditors' performance as confirmed in the studies by Wetzel et al. (2000) and Drake et al. (2007), however, the relationship with organizational committment is insignificant as aligned with the findings by Alam and Armanu (2010). Next, the relationship between role conflict and organizational committment has a significant result as found by Catharina (2001); Douglas (1996); Dubinsky et al. (1992); Keaveney and Nelson (1993); Siguaw et al. (1994) but not in the relationship with auditors' performance (value found to be insignificant). This is consistent with the findings in studies by Cahyono (2008) and Kreitner and Kinichki (1995).

Interestingly, both the relationships of organizational committment with the auditors' performance and turnover are significant, altogether confirming findings established by Dubisky et al. (1992); Kalbers and Fogarty (1995); Ketchand \& Strawser (1998); Pasewark and Strawser (1996); Suwandi and Indriantoro (1999); and Ratnawati (2000). Lastly, the influence of auditors' performance has a significant relationship with turnover, indicating the support for the findings by Drake et al. (2007). The implications of the research include several theoretical implications. This study successfully proves that there is a a significant relationship between auditor's empowerment and role conflict, role ambiguity and auditors' innovation, auditors' innovation and role conflict, role ambiguity and auditor's professionalism, auditors' professionalism and role conflict, role conflict and organizational commitment, role ambiguity and auditors' performance, organizational commitment and auditors' performance, organizational commitment and turnover intention, auditors' performance and turnover intention, auditors' empowerment and turnover intention, auditors' innovation and turnover intention as well as auditors' professionalism and turnover intention. 


\section{Reference}

Alam, R. \& Armanu, T. (2010). Pengaruh Pemberdayaan terhadap Kelelahan Kerja dan Kecerdasan emosional Perawat dan Bidan pada Rumah Sakit Palopo di Pare-pare dan Bone di Sulawesi Selatan (The Influence of Empowerment towards the Work Stress and Emotional Intelligence on Nurses and Midwife in Pare-Pare and Bone, South Sulawesi). Jurnal Aplikasi Manajemen, 8(1).

Andraeni, N. N. N. (2003). Pengaruh Stres Kerja terhadap Motivasi Kerja dan Kinerja Karyawan PT. H.M Sampoerna Tbk. Studi Pengembangan SDM (The Influence of Work Stress on Work Motivation and Employees' Performance at PT. H.M. Sampoerna Tbk.: A Study on Human Resource Development). Thesis Program Pasca Sarjana Universitas Airlangga. Surabaya.

Aranya, N., Pollock, J. \& Armenic, J. (1981). An Examination of Professional Commitment in Public Accounting. Accounting, Organizations and Society, 6(4), 271-280.

Aranya, N. \& Ferris, K. R. (1984). A reexamination of Accountants Organizational Professional Conflict. The Accounting Review, 60, 1-15.

Amilin, L. \& Dewi, R. (2008). Pengaruh Komitmen Organisasional terhadap Kepuasan Kerja Akuntan Publik dengan Role Stress sebagai Variabel Moderating. Jurnal Akuntansi dan Auditing Indonesia (JAAI), 12(1), 13-24.

Bamber, S. \& Tubbs, L. (1989). An Audit Structure and Its Relationship to Role Conflict and Role Ambiguity: An Empirical Investigation. The Accounting Review, 3, 285-299

Bao, B., Bao, D. \& Vasarheli, M. (1986). A stochastic model of Professional Accountant Turnover. Accounting, Organizations and Society, 11(3), 289-296

Bartlett, C. A. \& Ghoshal, K. (1993). Beyond the M-form: Toward a Managerial theory of the firm. Strategic Management Journal, 14, 23-46

Bateman, L. \& Stresser, J. (1984). A Longitudinal Analysis of the Antecedent of Organizational Commitment. Academy of Management Journal, 27, 94-112.

Bryman, A. \& Cramer, D. (2001). Quantitative Data Analysis with SPSS Release 10 for Windows, London: Routledge.

Burney, L. \& Widener, S. K. (2007). Strategic Performance Measurement Systems, Job Relevant Information, and Managerial Behavioral Responses Role Stress and Performance. Behavioral Research in Accounting, 19, 43-69.

Cahyono, D. (2008). Persepsi Ketidakpastian Lingkungan, Ambiguitas Peran dan Konflik Peran sebagai Mediasi Antara Program Mentoring dengan Kepuasan Kerja, Prestasi Kerja dan Niat Ingin Pindah. Studi Empiris di Lingkungan Kantor Akuntan Publik (KAP) Besar (The Perception of Environment Uncertainty, Role Ambiguity and Conflict as the Mediator between Mentoring Programme and Job Satisfaction, Performance, Turnover Intention: An Empirical Study in Public Accountant Firms). Disertasi Universitas Diponegoro. Semarang.

Catharina, F. (2001). Pengaruh Konflik dan Ambiguitas Peran Terhadap Kinerja Karyawan: Studi Kasus pada Departemen Call Center PT. Exelcomindo Pratama Jakarta (The Conflict Effect and Role Ambiguity on Employees' Performance: A Study at PT. Exelcomindo Pratama Jakarta). Tesis Program Studi Magister Manajemen, Universitas Diponegoro. Semarang.

Collins, K. M. (1993). Stress and Departure from the Public Accounting Profession: a Study of Genders Difference. Accounting Horrizons, 29-38.

Darlis, E. (2000), Analisis Pengaruh Komitment Organisasional dan Ketidakpastian Lingkungan terhadap Hubungan antara Partisipasi Anggaran dengan Senjangan Anggaran (An Analysis on Organizational Committement and Environment Uncertainty). Tesis Program Pascasarjana Universitas Gadjah Mada. Yogyakarta.

Douglas, M. E. (1996). Creating Eustress in The Workplace: A Supervisor's role, Supervision, 6-9.

Drake, A. R., Jeffrey, W. \& Stephen, B. S. (2007). Empowerment, Motivation and Performance; examining the Impact of Feedback and Incentive on Non Management Employees. Behavioral Research in Accounting. 19, 71-89

Dubinsky, A. J., Michaels, R. E., Kotabe, M., Lim dan Hee-Cheol Moon, C. U. (1992). Influence of Role Stress on Industrial Salespeople's work Outcomes in The United States, Japan and Korea. Journal of International Business Studies, 2, 77-99.

Ferris, K. (1981). Organizational Commitment and Performance in a Professional Accounting Firm. Accounting: Organizations and Society, 6, 317-325.

Fisher, R. T. (2001). Role stress, the Type A behavior Pattern, and External Auditor, Job satisfaction and Performance. Behavior Research and Accounting, 13, 164-176.

Fridati, W. (2005). Analisis Hubungan antara Professionalism Auditor dengan Pertimbangan Tingkat Materialitas dalam Proses Pengauditan Laporan Keuangan di Yogjakarta (An Analyis of 
Relationship of Auditors' Professionalism and Materials' Level in Audit Process of Financial Report in Yogjakarta). Skripsi. Fakultas Ekonomi. Universitas Islam Indonesia. . Yogyakarta

Kalbers, L. P. \& Forgatty, T. J. (1995). Professionalism and Its Consequences: A Study of Internal Auditors, Auditing. A Journal of Practice and Theory, 14(1), 64-86.

Keaveney, S. M. \& Nelson, J. E. (1993). Coping with Organizational Role Stress: Intrinsic Motivational Orientation, Perceived Role Benefit and Psychological Withdrawal. Journal of the Academy of Marketing Science, 21, 113-124.

Ketchand, A. A. \& Strawser, J. R. (2001). Multiple Dimensions of Organizational Commitment: Implications for Future Accounting Research. Behavioral Research in Accounting, 13, 221-251.

Khikmah, S. N. (2005). Pengaruh Professional Terhadap Keinginan Berpindah dengan Komitmen Organisasional dan Kepuasan Kerja Sebagai Variabel Intervening (Studi Empiris pada Auditor Se Jawa) (The Effect of Professionalism on Turnover Intention and Organizational Committment and Job Satisfaction as Intervening Variable). Tesis S2. Universitas Diponegoro.

King, L. A. \& King, D. W. (1990). Role conflict and role ambiguity: A critical assessment of construct validity. Psychological Bulletin, 107, 48-64

Kreitner, R. \& Kinichki, I. (2001). Organizational Behavior. McGraw Hill, New York.

Lampe, J. C. \& Earnest, K. R. (1984). How Motivation Effect Accountants' Productivity and Turnover. Management Accounting, 65(8), 64-86

Lum. L., Kervin, J., Clark, K., Reid, F. \& Sirola, W. (1998). Explaining Nurse Turnover Intent: Job Satisfaction, Pay Satisfaction, or Organizational Commitment? Journal of Organizational Behavior, $19,305-320$.

Marginson, L. (2002). Management control system and their effect on strategy formation at middle management level: Evidence from a U.K. organization. Strategic Management Journal, 23, 10191031

Margison, D. \& Binh, B. (2009). Examining the human Cost of Multiple Role Expectations. Behavioral Research in Accounting, 21(1), 59-81.

Meyer, J. P., Paunonen, S. V., Gellatly, I. R., Goffin, R. D. \& Jackson, D. N. (1989). Organizational commitment and job Performance: It's the Nature of the Commitment That Counts. Journal of Applied Psychology, 74(1), 152-156.

Miles, R. H. \& Perreault, W. D. (1976). Organization role conflict: Its antecedent and consequences. Organizations behavior and Human Performance, 17, 19-44.

O'Reilly, C. A., Chatman, J. \& Caldwell, D. F. (1991). People and Organization Culture. A Profile Comparison Approach to Assessing Person-Organization Fit. Academy of Management Journal, 34, 487-516.

Pasewark, W. R. \& Strawser, J . R. (1996). The Determinants and Outcomes Associated With Job Insecurity in a Professional Accounting Environment. Behavioral Research in Accounting, 8, 91-113.

Posner, B. Z. (1993). Value Congruence and Difference between the Interplay of Personal and Organization Value System. Journal of Business Ethics, 12(5), 341-347.

Pujisari, Y. (2001). Pengaruh Jenis Kelamin dan Peran Jenis Terhadap Kepuasan Kerja, Stres Kerja, dan Keinginan Berpindah (The Influence of Gender and Type of Roles towards Job Satisfaction, Work Stress and Turnover Intention). Tesis S2 Akuntansi Universitas Gadjah Mada. Yogyakarta

Ratnawati, V. (2000). Pengaruh Faktor Anteseden, Job Insecurity dan Konsekuensinya terhadap Keinginan Berpindah Karyawan (Studi Empiris Pada Kantor Akuntan Publik) (The Influence of Antecedent Factors, Job Insecurity and Consequences towards Turnover Intention). Tesis. Program Pascasarjana Universitas Gadjah Mada, Yogyakarta.

Robbins, P. S. (2003). Organizational Behavior. Ed. 9. New Jersey. Prentice Hall International Inc.

Schroeder, R. \& Scudder, E. E. (1989). Innovation in Manufacturing. Journal of Operation Manajemen, $8(1), 1-15$.

Siguaw, J. A., Gene B. \& Widing II, Jr., R. E. (1994). The Influence of the Market Orientation of the Firm on Sales Force Behavior and Attitudes. Journal of Marketing Research, 31, 106-116.

Spreitzer, G. (1996). Social structural characteristics of psychological empowerment. Academy of Management Journal, 39(2), 483-504.

Suwandi, H. \& Indriantoro, L. (1999). Pengujian Model Turnover Pasewark dan Strawser: Studi Empiris pada Lingkungan Akuntansi Publik. Jurnal Riset Akuntansi Indonesia, 2, 173-195.

Toly, A. A. (2001). Analisis Faktor-faktor yang Mempengaruhi Turnover Intention pada Staf Akuntan Publik (An Analysis of Fcators affect the Turnover Intention on Public Accountants Staff). Skripsi. Jurusan Ekonomi Akuntansi. Fakultas Ekonomi. Universitas Kristen Petra. http://Puslit.Petra. Ac.Id/Journals/accounting.

Wahyudi, H. \& Mardiyah, A. A. (2006). Pengaruh Profesionalisme Auditor Terhadap Tingkat Materialitas dalam Pemeriksaan Laporan Keuangan. Simposium Nasional Akuntansi IX. Padang, 1-26. 
Wetzel, M., de Ruyter, K. \& Bloemer, J. (2000). Antecedent and consequences of role stress of retail sales persons. Journal of Retailing and Customer Services, 7, 65-75

Williams, L. J. \& Hazer, J. T. (1986). Antecendents and Consequences of Satisfaction and Commitment in Turnover Models: A Reanalysis Using Laten Variable Structural Equation Methods. Journal of Applied Psychology, 71(2), 37-44.

Yousef, D. A. (2002). Job Satisfaction as a Mediator of the Relationship between Role Stressors and Organizational Commitment: A Study from an Arabic Cultural Perspective. Journal of Management Psychology, 17(4), 250-266. 